\title{
The cytoplasmic domain close to the transmembrane region of the glucagon-like peptide- 1 receptor contains sequence elements that regulate agonist-dependent internalisation
}

\author{
Patricia Vázquez, Isabel Roncero, Enrique Blázquez \\ and Elvira Alvarez \\ Departamento de Bioquímica y Biología Molecular, Facultad de Medicina, Universidad Complutense, Ciudad Universitaria, 28040 Madrid, Spain \\ (Requests for offprints should be addressed to Elvira Alvarez; Email: eao513@med.ucm.es)
}

\begin{abstract}
In order to gain better insight into the molecular events involved in the signal transduction generated through glucagon-like peptide-1 (GLP-1) receptors, we tested the effect of deletions and point mutations within the cytoplasmic tail of this receptor with a view to establishing relationships between signal transduction desensitisation and receptor internalisation. Wild-type and truncated (deletion of the last 27 amino acids (GLPR 435R) and deletion of 44 amino acids (GLPR 418R)) GLP-1 receptors bound the agonist with similar affinity. Deletion of the last 27 amino acids decreased the internalisation rate by $78 \%$, while deletion of 44 amino acids containing all the phosphorylation sites hitherto described in this receptor decreased the internalisation rate by only $47 \%$. Binding of the ligand to both receptors stimulated adenylyl cyclase. In
\end{abstract}

contrast, deletion of the region containing amino acids 419 to 435 (GLPR 419 4435 ) increased the internalisation rate by $268 \%$, and the replacement of $\mathrm{EVQ}^{408-410}$ by alanine (GLPR A ${ }^{408-410}$ ) increased this process to $296 \%$. In both receptors, the efficacy in stimulating adenylate cyclase was decreased. All the receptors studied were internalised by coated pits, except for the receptor with a deletion of the last 44 amino acids, which also had a faster resensitisation rate. Our findings indicate that the neighbouring transmembrane domain of the carboxyl-terminal tail of the GLP-1 receptor contains sequence elements that regulate agonist-dependent internalisation and transmembrane signalling.

Journal of Endocrinology (2005) 186, 221-231

\section{Introduction}

The internalisation of cell surface receptors is a process that mediates many functions, such as their own desensitisation, resensitisation, and down-regulation processes that modulate receptor responsiveness. The group of G-proteincoupled receptors, whose main function is to transduce information from the extracellular environment to the interior of the cell, initiates this process after a specific ligand has been bound to its receptor, thereby facilitating transmembrane signalling. Both clathrin-coated pits (Ghinea et al. 1992, Von Zastrow \& Kobilka 1992, Hoxie et al. 1993, Von Zastrow et al. 1993, Roettger et al. 1995) and uncoated endocytic pathways (Raposo et al. 1989, Roettger et al. 1995) have been suggested to be involved in the internalisation of G-protein-coupled receptors. Clathrin-coated pits require cytoplasmic receptor motifs in order to interact with proteins of the endocytic machinery (Trowbridge et al. 1993, Clague 1998). Intracytoplasmic internalisation domains containing tyrosine have been identified for several receptors containing a single trans- membrane domain (Chang et al. 1993, Sorkin \& Carpenter 1993, Ohno et al. 1995). Endocytic domains have also been identified for several members of heptahelical G-protein-coupled receptors (Ferguson 2001), but no common endocytic motif has been identified. In some cases, sequences including aromatic amino acids are required (Thomas et al. 1995, Böhn et al. 1997a), while serine- and threonine-rich sequences in the third cytoplasmic loop or cytoplasmic tail are necessary for efficient internalisation to be achieved (Hausdorff et al. 1991, Benya et al. 1993, Widmann et al. 1997). Agonist binding induces the phosphorylation of serine and threonine residues of many G-protein-coupled receptors, and phosphorylated domains are recognised by $\beta$-arrestins, which act as adaptor proteins that also bind to clathrin (Ferguson et al. 1996, Goodman et al. 1996). Dileucine sequences have also been shown to bind adaptor proteins and to promote internalisation through clathrin-coated pits (Ferguson 2001). It is not clear whether both clathrin-coated pits and uncoated endocytic pathways play a similar role. The cholecystokinin receptor-ligand complex internalised by 
uncoated pits has been purported to mediate rapid resensitisation of the receptor (Roettger et al. 1995).

Receptor desensitisation is a regulatory process through which cells attenuate their biological response (Lohse 1993, Freedman \& Lefkowitz 1996, Böhn et al. 1997b). G-protein-coupled receptors are desensitised by two mechanisms: homologous desensitisation, which is an agonist-specific response, and heterologous desensitisation, which is a process dependent on the activation of a different receptor. Desensitisation is mediated by receptor phosphorylation and arrestins may bind to phosphorylated receptors and cause uncoupling from G-proteins (Böhn et al. 1997b). This process may be followed by internalisation in acidified endosomes (Ferguson et al. 1996, Goodman et al. 1996). Following this, receptors are dephosphorylated, recycling to the cell surface being necessary for resensitisation (Pipping et al. 1995, Garland et al. 1996).

Recently, the presence of anchoring and scaffold proteins bound to subcellular structures and associated with protein kinases, protein phosphatases and adaptor proteins has been reported. This may facilitate the action of these proteins involved in the signalling process (Pawson \& Scott 1997).

The glucagon-like peptide-1 (GLP-1) receptor is a member of the G-protein-coupled receptor subfamily (Dillon et al. 1993, Thorens 1993, Thorens et al. 1993, Alvarez et al. 1996), which includes secretin, calcitonin, parathyroid hormone (PTH), vasoactive intestinal peptide, glucose-dependent insulinotrophic polypeptide, glucagonlike peptide-2 (GLP-2), and glucagon receptors. GLP-1 receptors mediate the effects of GLP-1(7-36)amide or GLP-1(7-37) on peripheral tissues, such as the stimulation of glucose-induced insulin secretion (Kreymann et al. 1987, Weir et al. 1989), arterial blood pressure, and pulmonary surfactant production (Barragán et al. 1994, Benito et al. 1998), and in the central nervous system they exert an inhibitory effect on food and water intake (Navarro et al. 1996, Tang-Christensen et al. 1996, Turton et al. 1996, Rodriguez de Fonseca et al. 2000). GLP-1 has a therapeutic potential in patients with type 2 diabetes. Treatment with this peptide lowers plasma glucose in diabetic subjects (Toft-Nielsen et al. 1999). It has been reported that the internalisation of the GLP-1 receptor is mainly mediated by clathrin-coated pits (Widmann et al. 1995), and that it can be prevented through use of a mutant receptor lacking 33 amino acids from the C-terminal tail containing three phosphorylation sites (Widmann et al. 1996, 1997). We attempted to use a GLP-1 receptor lacking the 44 amino acids from the C-terminal tail and we found only a $47 \%$ slower internalisation rate than with wild-type receptors. In an effort to gain a better understanding of the molecular events involved in the internalisation and signal transduction generated through GLP-1 receptors, here we characterised different mutants of GLP-1 receptors, allowing us to study the relationship between signal transduction and receptor internalisation. Thus, we tested the effect of deletions and also point mutations of the amino acids $\mathrm{E}^{408}, \mathrm{~V}^{409}$ and $\mathrm{Q}^{410}$ within the cytoplasmic tail of the GLP-1 receptor. Our results indicate that the domain close to transmembrane region VII of the cytoplasmic tail of GLP-1 receptors also has sequence elements involved in the regulation of agonist-dependent internalisation and in the transmembrane signalling process.

Investigation of the signalling and desensitisation of the GLP-1 receptor is of considerable physiological and pathological importance. The activation of signalling through these receptors and the overexpression of the GLP-1 receptor have been proposed as therapeutic strategies for the treatment of neurodegenerative processes and to improve glucose-dependent insulin synthesis and secretion.

\section{Materials and Methods}

\section{Mutagenesis of the GLP-1 receptor}

A HindIII-XbaI fragment of rat GLP-1 receptor cDNA (Thorens 1993) was subcloned into PUC 18. Site-directed mutagenesis was carried out using the Transformer sitedirected mutagenesis kit from Clontech (Palo Alto, CA, USA). A silent mutation strategy was used to create a BfrI restriction site at nucleotide 1322, using a mutagenic primer (5' CCCCTTAAGTGTCCCACCAGC $3^{\prime}$ ) and a selection primer (5' GTGTATCTTATGCCAAGTACG $\left.3^{\prime}\right)$ to eliminate a unique $\mathrm{NdeI}$ restriction site in the vector. A clone (BfrI) was selected and mutation was confirmed by sequencing, using an automated LKB ALF DNA sequencer (Amersham Pharmacia Biotech, Barcelona, Spain).

PUC18-GLPR BfrI was used to eliminate residues 436463. The plasmid was cleaved with BfrI and PstI, followed by treatment with mung bean nuclease to generate blunt ends, after which the plasmid was religated. PUC 18GLPR BfrI was also used to eliminate residues 419-435. In this case, the plasmid was cleaved with BfrI, followed by fill-in of 5' overhangs to generate blunt ends. After Eco47 III digestion, the plasmid was religated. The sequence was confirmed by sequencing, using an automated LKB ALF DNA sequencer. HindIII-XbaI mutant cDNAs were then cloned into the expression vector pcDNA3 (pcDNA3-GLPR 435R and pcDNA3-GLPR 4194435).

pcDNA3-GLPR was digested with Eco47 III and PstI, and this was followed by treatment with mung bean nuclease to eliminate single-stranded extensions. Finally, the plasmid was religated (pcDNA3-GLPR 418R). The sequence was confirmed by sequencing, using an automated LKB ALF DNA sequencer.

For substitution of amino acids $\mathrm{E}^{408}, \mathrm{~V}^{409}$, and $\mathrm{Q}^{410}$ by alanine, PCR site-directed mutagenesis was used, employing standard procedures. The following primers were used: two flanking primers - GLPR-1 oligonucleotide, 
corresponding to nucleotides 969-993 and GLPR-2 oligonucleotide, corresponding to nucleotides 1384-1411 (Thorens 1993); the specific mutation primers GLPR-3 (5' TGTCAACAATGCGGCCGCGATGGAGTTTCG $\left.3^{\prime}\right)$ and GLPR-4 (5' TCCATCGCGGCCGCATTGTT GACAAAG $3^{\prime}$ ) were used to mutate EVQ into alanine residues. Mutation identity was verified by sequence analysis using an automated LKB ALF DNA sequencer. The fragments containing the mutated gene were subcloned into the SacI/PstI restriction sites of pcDNA3GLPR to create (pcDNA3-GLPR A ${ }^{408-410}$ ). GLP-1 receptors were expressed in $\mathrm{CHO}$ cells by transfection, using the calcium phosphate method (Chen \& Okayama 1987). Transfected cells were selected by incubation with neomycin (400 mg/l) (geneticin, GIBCO, Life Technologies, Barcelona, Spain). Stable colonies were isolated using cloning rings.

\section{Binding of ${ }^{125} I$-GLP-1(7-36) amide to cell surface receptors}

GLP-1(7-36)amide was radiolabelled with ${ }^{125} \mathrm{I}$ by the Chloramine T method and mono ${ }^{125}$ I-GLP-1(7-36)amide was isolated by reverse-phase HPLC (Calvo et al. 1995). Specific activity was between 3500 and 4000 d.p.m./fmol. Cells grown in 24 -well plates $\left(2 \times 10^{5} /\right.$ well $)$ were washed with serum-free medium and incubated for $30 \mathrm{~min}$ at $37^{\circ} \mathrm{C}$ in $\mathrm{KRH}(118 \mathrm{mM} \mathrm{NaCl}, 5 \mathrm{mM} \mathrm{KCl}, 1.2 \mathrm{mM}$ $\mathrm{MgSO}_{4}, 2.5 \mathrm{mM} \mathrm{CaCl}, 25 \mathrm{mM}$ HEPES, $\mathrm{pH} 7 \cdot 4$ ) with $0.5 \%$ bovine serum albumin (BSA). Then, cells were chilled on ice, and ${ }^{125}$ I-GLP-1(7-36)amide $(0 \cdot 1 \mathrm{nM})$ and unlabelled GLP-1(7-36)amide $(0-500 \mathrm{nM})$ were added for $16 \mathrm{~h}$ at $4{ }^{\circ} \mathrm{C}$. Following this, cells were washed three times with cold medium and solubilised with $1 \mathrm{M} \mathrm{NaOH}$. Non-specific binding of ${ }^{125}$ I-GLP-1(7-36)amide was estimated in the presence of $500 \mathrm{nM}$ unlabelled ligand, and this value was subtracted from the total binding values. For covalent cross-linking analysis, ${ }^{125}$ I-GLP-1(7-36)amide was bound as described above. The cells were washed twice with cold medium, washed in the same medium without BSA, and cross-linking was initiated by the addition of $0.5 \mathrm{mM}$ disuccinimidyl suberate (DSS) for $15 \mathrm{~min}$ at $4{ }^{\circ} \mathrm{C}$. The reaction was quenched with $10 \mathrm{mM}$ Tris- $\mathrm{HCl}, \mathrm{pH} 7 \cdot 4$, and $1 \mathrm{mM}$ EDTA and solubilised with Laemmli sample buffer (Laemmli 1970), and samples were analysed by SDS-PAGE and autoradiography.

\section{cAMP production assays}

cAMP levels were measured with the cAMP Biotrack enzyme immunoassay system (Amersham Pharmacia Biotech) following the manufacturer's instructions. Briefly, untransfected $\mathrm{CHO}$ cells and cells expressing wild-type and mutant GLP-1 receptors were grown in 12-well plates in F-12 medium supplemented with 5\% FBS. CHO cells were washed and incubated in F-12 medium containing $0 \cdot 1 \%$ FBS overnight. Cells were then washed with HBS medium $\left(130 \mathrm{mM} \mathrm{NaCl}, 0.9 \mathrm{mM} \mathrm{NaH}{ }_{2} \mathrm{PO}_{4}, 0.8 \mathrm{mM}\right.$ $\mathrm{MgSO}_{4}, 5 \cdot 4 \mathrm{mM} \mathrm{KCl}, 1 \cdot 8 \mathrm{mM} \mathrm{CaCl}, 20 \mathrm{mM}$ HEPES, $\mathrm{pH} 7 \cdot 4$, plus $25 \mathrm{mM}$ glucose) and incubated in HBS containing $1 \mathrm{mM} \mathrm{IBMX}$ and $0 \cdot 1 \% \mathrm{BSA}$ in the presence or absence of different concentrations of GLP-1(7-36)amide $(0 \cdot 001-100 \mathrm{nM})$ for $8 \mathrm{~min}$. Then, cells were washed with HBS, treated with lysis buffer, and immediately processed for immunoassay. In parallel experiments, the binding of ${ }^{125}$ I-GLP-1(7-36)amide to cell surface receptors was determined at $4{ }^{\circ} \mathrm{C}$. Agonist-stimulated cAMP production was normalised by ${ }^{125}$ I-GLP-1(7-36)amide bound to cell surface receptors.

\section{Detection of phospho ERK1/ERK2}

CHO cells expressing wild-type and mutant GLP-1 receptors were washed and incubated in F-12 medium containing $0 \cdot 2 \%$ FBS overnight. Cells were treated in the absence or presence of $10 \mathrm{nM}$ GLP-1(7-36)amide for different times and were subsequently lysed in $25 \mathrm{mM}$ HEPES ( $\mathrm{pH} 7 \cdot 4$ ), 1\% Triton X-100, 1\% deoxycholate, $0 \cdot 1 \%$ SDS, $5 \mathrm{mM}$ EDTA, $500 \mathrm{mM} \mathrm{NaCl}, 50 \mathrm{mM} \mathrm{NaF}$, $5 \mathrm{mM}$ pyrophosphate, $1 \mathrm{mM}$ orthovanadate, $10 \mu \mathrm{M}$ leupeptin and $1 \mathrm{mM}$ PMSF. Proteins from each sample $(50 \mu \mathrm{g})$ were resolved by SDS-PAGE and electrotransferred onto a nitrocellulose filter. After blocking in TBS $(20 \mathrm{mM}$ Tris, $\mathrm{pH} 7 \cdot 4$, and $150 \mathrm{mM} \mathrm{NaCl})$ containing $0 \cdot 1 \%$ Tween-20 and 5\% non-fat dry milk overnight at $4{ }^{\circ} \mathrm{C}$, the filter was incubated in TBS $2 \%$ non-fat dry milk $0 \cdot 1 \%$ Tween-20 with a polyclonal (1: 1000) phosphospecific anti-ERK antibody obtained from New England Biolabs (Beverly, MA, USA) for $1-2 \mathrm{~h}$ at room temperature. After washing off excess antibody, the filters were incubated with an anti-rabbit horseradish peroxidaseconjugated secondary antibody (1: 3000) (Amersham Pharmacia Biotech) for $1 \mathrm{~h}$ at room temperature. Chemiluminescence detection was carried out using the ECL reagents.

\section{Internalisation of the GLP-1 receptor}

The internalisation rate was measured as previously described (Alvarez et al. 1990). Briefly, CHO cells were incubated in $\mathrm{KRH}$ with $0.5 \% \mathrm{BSA}$ at $37^{\circ} \mathrm{C}$ for $30 \mathrm{~min}$. Then, cells were incubated with $0 \cdot 1 \mathrm{nM}{ }^{125} \mathrm{I}-$ GLP-1(736)amide, and ${ }^{125}$ I-GLP-1(7-36)amide binding was determined at different times. Intracellular ${ }^{125}$ I-GLP-1(736)amide was measured as cell-associated radioactivity resistant to acid wash by incubation of the cells for $3 \mathrm{~min}$ at $4{ }^{\circ} \mathrm{C}$ with $50 \mathrm{mM} \mathrm{NaCl}, 150 \mathrm{mM}$ glycine (pH 3.0). Cell surface-bound ${ }^{125} \mathrm{I}-\mathrm{GLP}-1(7-36)$ amide was calculated by subtraction of the intracellular bound ${ }^{125}$ I-GLP1(7-36)amide from the total binding.

\section{Redistribution of cell surface GLP-1 receptors}

$\mathrm{CHO}$ cells were seeded in 24-well plates and incubated with $10 \mathrm{nM}$ GLP-1(7-36)amide for different times (3, 6, 


\title{
PRIMARY STRUCTURE
}

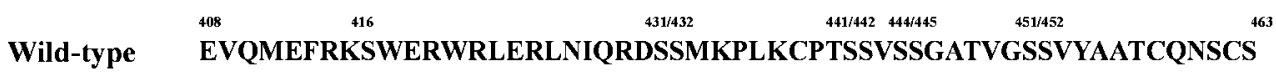

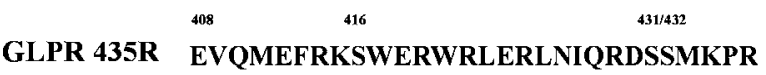

GLPR 418R $\stackrel{408}{40 V Q M E F R K S W E R}$

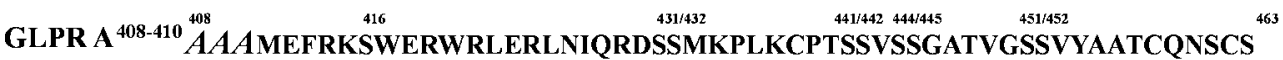

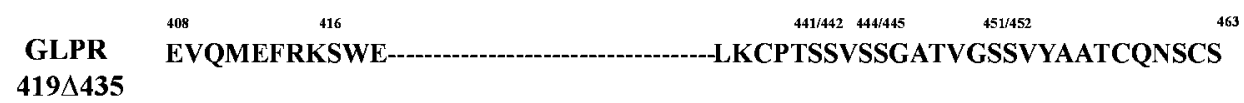

Figure 1 Primary structure of the C-terminal tail from the wild-type and mutants of the GLP-1 receptor. The 56 C-terminal amino acids of the wild-type rat GLP-1 receptor and their mutants are shown.

$10,15,30$ and $60 \mathrm{~min})$. Then, cells were washed at $0{ }^{\circ} \mathrm{C}$ and subsequently incubated for $3 \mathrm{~min}$ at $0{ }^{\circ} \mathrm{C}$ with $50 \mathrm{mM}$ $\mathrm{NaCl}, 150 \mathrm{mM}$ glycine $(\mathrm{pH} \mathrm{3.0)}$ to remove ligand bound to the cell surface and washed with $\mathrm{KRH}$ containing $0 \cdot 5 \%$ BSA. Cell surface receptors were then measured as described above.

Effect of metabolic inhibitors and hypertonic medium on the internalisation process

For metabolic depletion, CHO cells were washed twice with glucose-free HBS buffer and incubated in the same buffer containing $20 \mathrm{mM}$ 2-deoxyglucose and $10 \mathrm{mM}$ sodium azide. Hypertonic treatment was performed as previously described (Heuser \& Anderson 1989, Hansen et al. 1993). Briefly, cells were washed twice with HBS containing $0.45 \mathrm{M}$ sucrose and incubated in the same medium for $30 \mathrm{~min}$ at $37^{\circ} \mathrm{C}$. Then, cells were incubated with $0 \cdot 1 \mathrm{nM}{ }^{125}$ I-GLP-1(7-36)amide and after a 6-min incubation cell-associated radioactivity and acid wash-resistant radioactivity were measured as previously described.

\section{Data analysis}

Data for competition experiments were analysed by nonlinear regression with the GraphPad Prism computer program (GraphPad Software, San Diego, CA, USA). Dissociation constants $\left(K_{\mathrm{d}}\right)$ and concentrations of receptor sites $\left(\mathrm{B}_{\max }\right)$ were calculated from $\mathrm{IC}_{50}$ values using the method of Cheng and Prusoff (1973). Data are expressed as means \pm S.E.M. Statistical comparisons were performed using the Student's $t$-test and Newman-Keuls test with at least three separate experiments performed in duplicate.

\section{Results}

Kinetics of ${ }^{125}$ I-GLP-1(7-36)amide internalisation

A series of mutant receptors containing deletions and point mutations within the cytoplasmic tail of GLP-1 receptors was constructed (Fig. 1).

The rate of GLP-1 receptor internalisation was measured in cells expressing wild-type and GLPR 435R and GLPR 418R mutant receptors after the determination of total cell-associated and acid wash-resistant radioactivity as a function of time. A linear rate of ${ }^{125} \mathrm{I}-\mathrm{GLP}-1$ (736)amide internalisation was observed up to $8 \mathrm{~min}$ in cells expressing wild-type and mutant receptors (Fig. 2). The apparent first-order endocytic rate constant was $0 \cdot 196 \pm$ $0.016 \mathrm{~min}^{-1}$ for wild-type receptors: i.e. quite different from that obtained with mutant receptors (Table 1). As compared with the cells with the wild-type receptor, the rate of internalisation decreased by $78 \%$ in cells expressing receptors with the deletion of 27 amino acids in the C-terminal tail (GLPR 435R), while the deletion of 44 amino acids in the same region (GLPR 418R) produced a $47 \%$ decrease. The rate of internalisation of GLP-1 receptors was also similar in a pool of clones expressing the wild-type and mutant GLP-1 receptors.

\section{Binding studies}

$\mathrm{CHO}$ cells expressing wild-type or mutant receptors were used to analyse their binding properties with 


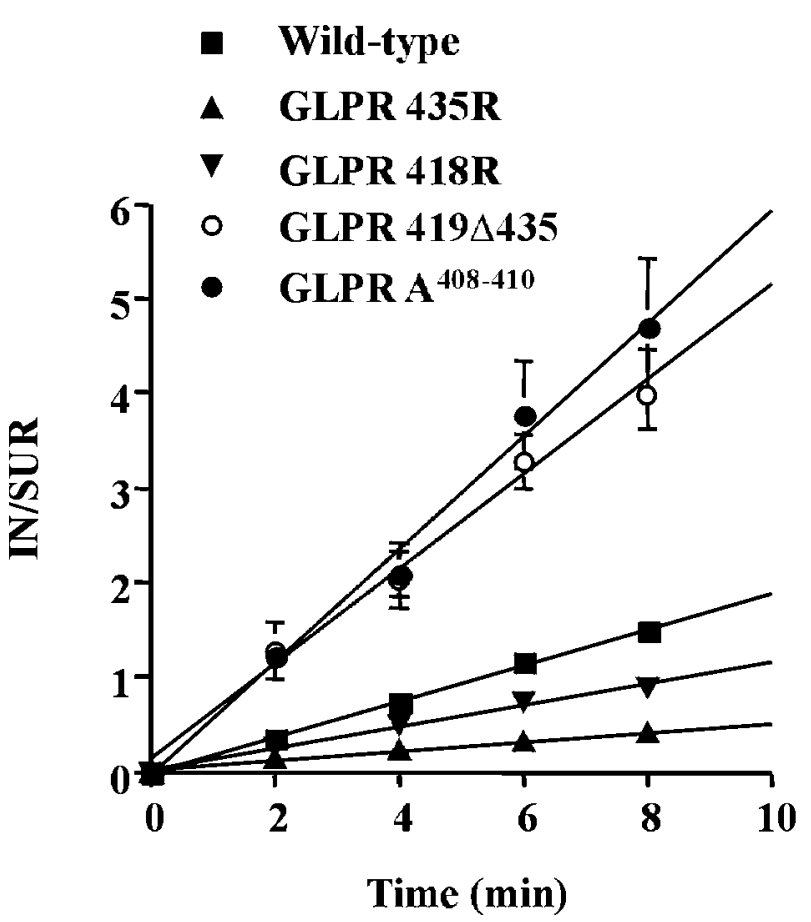

Figure 2 Endocytosis of ${ }^{125}$ I-GLP-1(7-36)amide by $\mathrm{CHO}$ cells transfected with wild-type and mutant GLP-1 receptors. The rate of ${ }^{125}$ I-GLP-1(7-36)amide endocytosis was measured in $\mathrm{CHO}$ cells expressing wild-type, GLPR 435R, GLPR 418R, GLPR A $A^{408-410}$ and GLPR $419 \Delta 435$ GLP-1 receptors. Cells were incubated with $0 \cdot 1 \mathrm{nM}^{125} \mathrm{I}$-GLP-1(7-36)amide and total and acid wash-resistant (intracellular) cell-associated radioactivity was measured at different times. The data are represented in the form of an IN/SUR plot, means \pm S.E.M. $(n=6)$. IN, intracellular ${ }^{125}$ I-GLP-1(7-36)amide; SUR, cell surface-bound ${ }^{125}$ I-GLP-1(7-36)amide. The first-order endocytic rate constants calculated from this data are shown in Table 1.

GLP-1(7-36)amide. The data from the competition binding assays are shown in Fig. 3A. The $K_{\mathrm{d}}$ and $\mathrm{B}_{\max }$ calculated from the $\mathrm{IC}_{50}$ values are shown in Table 2 and revealed a similar pattern of displacement of the radioactive peptide by increasing amounts of the unlabelled peptide in the wild-type, GLPR 435R- and GLPR

Table 1 Kinetic rate constant for GLP-1 receptor endocytosis. The first-order rate constant for the endocytosis of GLP-1 receptors was estimated from the data of Fig. 2. The results represent the means \pm S.E.M. of six independent experiments

\section{Endocytosis rate} $\left(\min ^{-1}\right)$

Receptor

Wild-type

GLPR 435R

GLPR $418 R$

GLPR A ${ }^{408-410}$

GLPR $419 \Delta 435$

\begin{tabular}{|c|c|}
\hline $0 \cdot 196 \pm 0 \cdot 016$ & 100 \\
\hline $0.0426 \pm 0.003$ & $21 \cdot 73$ \\
\hline $0 \cdot 104 \pm 0 \cdot 011$ & $53 \cdot 06$ \\
\hline $0.58 \pm 0.079$ & 296 \\
\hline $458 \pm$ & 233. \\
\hline
\end{tabular}

A

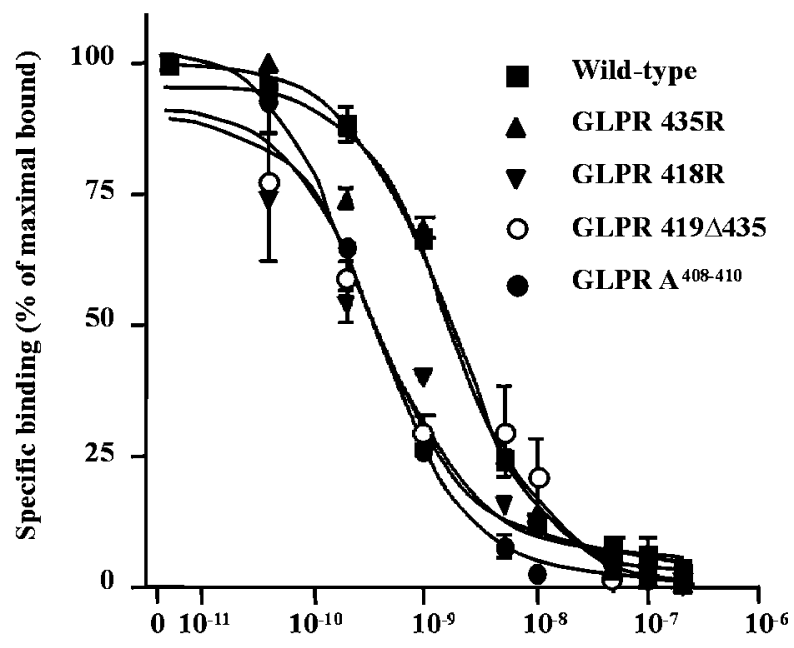

GLP-1(7-36)amide [M]

\section{B}

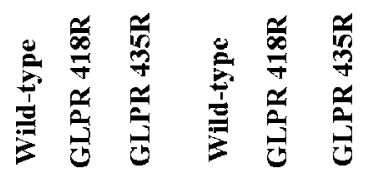

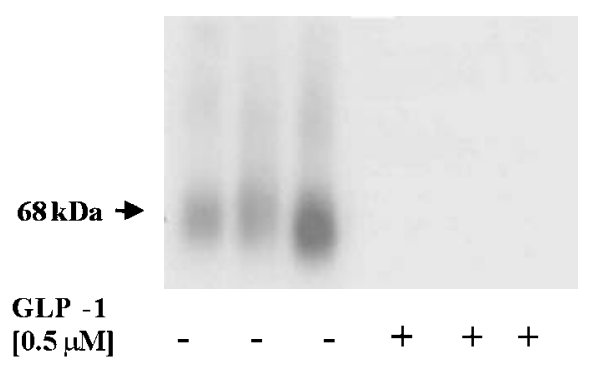

Figure 3 Analysis of ${ }^{125}$ I-GLP-1(7-36)amide binding to wild-type and mutant GLP-1 receptors and cross-linking of

${ }^{125}$ I-GLP-1 (7-36)amide bound to GLP-1 receptors. (A) CHO cells expressing wild-type, GLPR 435R, GLPR 418R, GLPR A A $^{408-410}$ and GLPR $419 \Delta 435$ GLP-1 receptors were incubated with $0 \cdot 1 \mathrm{nM}$ ${ }^{125}$ I-GLP-1(7-36)amide and increasing concentrations of unlabelled peptide. The competition binding curves are shown. Data are means \pm S.E.M. $(n=3-6)$ and were expressed as percent of maximal specific binding. (B) Covalent cross-linking analysis of ${ }^{125}$ I-GLP-1(7-36)amide binding to $\mathrm{CHO}$ cells expressing wild-type and mutant GLP-1 receptors. The cells were incubated with ${ }^{125}$ I-GLP-1 (7-36)amide in the presence $(+)$ or absence $(-)$ of $0.5 \mu \mathrm{M}$ unlabelled GLP-1(7-36)amide for $16 \mathrm{~h}$ at $4{ }^{\circ} \mathrm{C}$. The cells were washed and cross-linking was initiated by treatment with $0.5 \mathrm{mM}$ DSS for $15 \mathrm{~min}$ at $4{ }^{\circ} \mathrm{C}$. Autoradiograms of

${ }^{125}$ I-GLP-1(7-36)amide-receptor complexes as indicated by the arrow are shown.

418R- expressing cell lines. The competition binding data of wild-type and mutant receptors best fitted a single-site model. 
Table 2 GLP-1(7-36)amide binding parameters and adenylyl cyclase stimulation for wild-type and mutant GLP-1 receptors expressed in $\mathrm{CHO}$ cells. The GLP-1(7-36)amide binding parameters were determined by competitive binding assays using $\mathrm{CHO}$ cells stably transfected with wild-type and mutant GLP-1 receptors. The data were analysed by non-linear regression and the dissociation constant $\left(K_{\mathrm{d}}\right)$ and the concentrations of receptor sites $\left(B_{\max }\right.$ ) of these receptors were calculated from IC $\mathrm{C}_{50}$ values as described in Materials and Methods. The data on adenylyl cyclase activity were analysed using non-linear least squares regression. The agonist potency $\mathrm{EC}_{50}$ and maximal GLP-1(7-36)amide-stimulated adenylyl cyclase activity $\left(R_{\max }\right)$ are shown. Data represent the means \pm S.E.M. of three-six independent experiments

\section{${ }^{125}$ I-GLP-1 binding parameters}

\begin{tabular}{ll}
\hline$K_{\mathrm{d}}$ \\
$(\mathrm{nM})$
\end{tabular}$\quad \begin{aligned} & \mathrm{B}_{\max } \\
& \left(\mathrm{fmol} / 2 \times 10^{5} \text { cells }\right)\end{aligned}$

\section{Receptor}

Wild-type

GLPR 435R

GLPR 418R

GLPR $419 \Delta 435$

GLPR A $A^{408-410}$

$1 \cdot 46 \pm 0 \cdot 08$
$1 \cdot 62 \pm 0 \cdot 17$
$0 \cdot 35 \pm 0 \cdot 068$
$0 \cdot 28 \pm 0 \cdot 07$
$0 \cdot 25 \pm 0 \cdot 006$

$$
\begin{aligned}
12 & \pm 1 \cdot 65 \\
32 \cdot 22 & \pm 1 \cdot 91 \\
11 \cdot 83 & \pm 3 \cdot 14 \\
0 \cdot 46 & \pm 0 \cdot 24 \\
3 \cdot 19 & \pm 0 \cdot 1
\end{aligned}
$$

Adenylyl cyclase stimulation

\begin{tabular}{ll}
\hline $\mathrm{EC}_{50}$ & $\mathrm{R}_{\max }$ \\
$(\mathrm{nM})$ & $\left(\mathrm{pmol} / 2 \times 10^{5}\right.$ cells $)$
\end{tabular}

$6 \cdot 3 \pm 1 \cdot 4$

$10 \cdot 7 \pm 0 \cdot 6$

$6 \cdot 6 \pm 0 \cdot 29$

$3 \cdot 57 \pm 1 \cdot 3$

$2 \cdot 19 \pm 0 \cdot 016^{*}$

${ }^{\star} P<0 \cdot 05$ compared with cells expressing wild-type receptors (Newman-Keuls test)

The identification of ${ }^{125}$ I-GLP-1(7-36)amide-receptor complexes using a cross-linking assay is shown in Fig. 3B. In all cases, a single labelled band with a molecular mass of $64-68 \mathrm{kDa}$ in cells expressing the wild-type receptor $(68 \mathrm{kDa})$ and mutant truncated receptor was found; labelling of the ligand-receptor complex disappeared in the presence of unlabelled GLP-1(7-36)amide.

\section{Activation of adenylate cyclase}

Agonist binding to the GLP-1 receptor resulted in the stimulation of adenylate cyclase, as determined by the increase in intracellular cAMP contents. The doseresponse curve after GLP-1(7-36)amide treatment of $\mathrm{CHO}$ cells expressing wild-type receptors is shown in Fig. 4. The agonist stimulated cAMP production in a dosedependent manner in $\mathrm{CHO}$ cells expressing wild-type receptors; the $\mathrm{EC}_{50}$ of GLP-1(7-36)amide was $0.18 \pm$ $0 \cdot 04$, maximal stimulation $\left(\mathrm{R}_{\max }\right)$ being observed at $10 \mathrm{nM}$ dose of agonist (Table 2). CHO cells expressing GLPR 435R and GLPR 418R showed a similar potency and efficacy in stimulating cAMP production (Fig. 4, Table 2). Similar results were obtained using a pool of clones expressing the wild-type and mutant GLP-1 receptors.

\section{Effect on mitogen-activated protein kinase pathways}

The stimulation of mitogen-activated protein (MAP) kinase pathways by the GLP-1 receptor has been reported. We therefore investigated the ability of wild-type and mutant receptors to interact with this pathway by determining the level of ERK1/ERK2 phosphorylation after GLP-1(7-36)amide treatment (Fig. 5). Stimulation of $\mathrm{CHO}$ cells expressing wild-type receptors with $10 \mathrm{nM}$ agonist produced an increase in the phosphorylated forms of ERK1/ERK2, the maximum effect being observed after 5-min treatment, thereafter decreasing progressively after longer exposure times.

CHO cells expressing GLPR 435R and GLPR 418R receptors showed an increase in phosphorylated ERK1/ ERK2 proteins; the maximum effect persisted for $15 \mathrm{~min}$, thereafter decreasing progressively at longer times of exposure to the agonist.

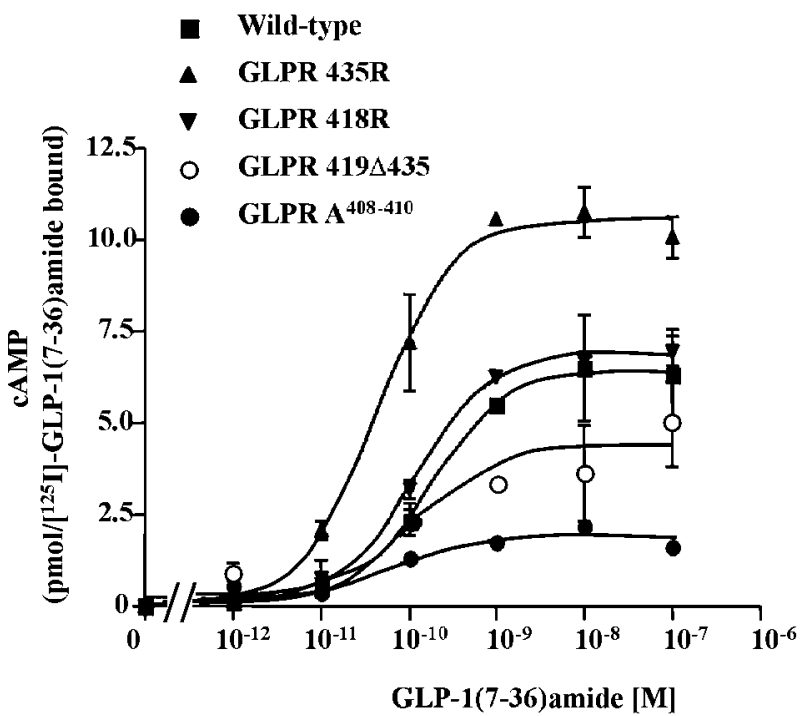

Figure 4 cAMP production after stimulation with GLP-1(7-36)amide. CHO cells expressing wild-type, GLPR 435R, GLPR 418R, GLPR $419 \Delta 435$ and GLPR A ${ }^{408-410}$ GLP-1 receptors were stimulated with different concentrations $(0 \cdot 1 \mathrm{nM}-1 \mu \mathrm{M})$ of GLP-1(7-36)amide for $8 \mathrm{~min}$ and the production of CAMP was determined by enzyme immunoassay. The data obtained were normalised by the number of cell surface receptors measured in parallel by binding assays. The data presented are means \pm S.E.M. of three separate experiments performed in duplicate. 
Characterization of GLP-1 receptors with a deletion of amino acids 419-435 and effect of the substitution of $E^{408}, V^{409}$, and $\mathrm{Q}^{410}$ by alanine

The effect of the deletion of amino acids 419-435 on the rate of GLP-1 receptor internalisation was measured after the determination of total cell-associated and acid washresistant radioactivity as a function of time. As shown in Fig. 2 the apparent first-order endocytic rate constant was $0.46 \pm 0.023 \min ^{-1}$ and the substitution of $\mathrm{E}^{408}, \mathrm{~V}^{409}$, and $\mathrm{Q}^{410}$ by alanine also caused an increase in the rate of endocytosis: $0.58 \pm 0.08 \mathrm{~min}^{-1}$ compared with $0 \cdot 196 \pm$ 0.016 min $^{-1}$, the value for wild-type receptors. In contrast, deletion of amino acids 419-435 and substitution by alanine at residues $408-410$ did not modify the potency in stimulating cAMP production (Fig. 4, Table 2). However, the mutant receptors showed a decreased efficacy as compared with the wild-type receptor (Table 2). The data from studies designed to analyse the agonist-binding properties are shown in Fig. 3A. The $K_{\mathrm{d}}$ and $\mathrm{B}_{\max }$ calculated from the $\mathrm{IC}_{50}$ values are shown in Table 2 . These data indicate that both mutations produce minor effects on agonist affinity, but the number of cell surface receptors is dramatically reduced as compared with wildtype receptors (Table 2).

\section{Redistribution of GLP-1 receptors in the presence of agonist}

The continued exposure to the agonist produces desensitisation, with a progressive decrease in the cell surface numbers of GLP-1 receptors. Accordingly, the effect of $10 \mathrm{nM}$ GLP-1(7-36)amide pretreatment on the number of cell surface GLP-1 receptors was measured (Fig. 6A). In cells expressing wild-type receptors, receptor numbers at the cell surface decreased to $46 \cdot 6 \pm 4 \cdot 5 \%$ of the initial values during the first $15 \mathrm{~min}$ of incubation, thereafter continuing to fall slowly to $36 \pm 3 \cdot 9 \%$ after $1 \mathrm{~h}$. However, the number of cell surface receptors in cells expressing GLPR 435R and GLPR 418R decreased much more slowly, with only a $15-20 \%$ reduction after $15 \mathrm{~min}$, while treatment with GLP-1(7-36)amide for only $3 \mathrm{~min}$ decreased cell surface receptors to $37 \%$ in cells expressing GLPR $419 \Delta 435$ and to $20 \%$ in cells expressing GLPR $\mathrm{A}^{408-410}$.

Effect of metabolic inhibitors and hypertonic medium on the internalisation process

To study whether wild-type and mutant GLP-1 receptors are internalised by clathrin-coated pits, the rate of internalisation was also measured on metabolically depleted cells to analyse whether this process was energy-dependent, and also in the presence of hypertonic medium, which prevents membrane-associated clathrin lattices from being formed and the formation of clathrin-coated vesicles. Under both experimental conditions - metabolic depletion

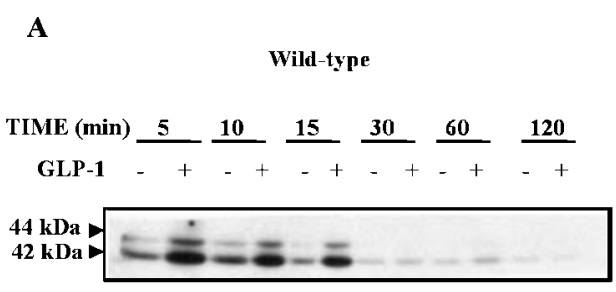

$\mathbf{B}$ GLPR 435R

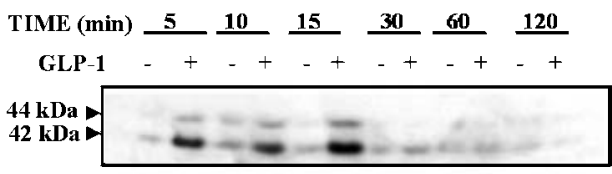

C

GLPR 418R

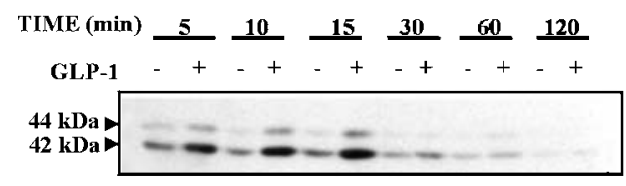

$\mathbf{D}$

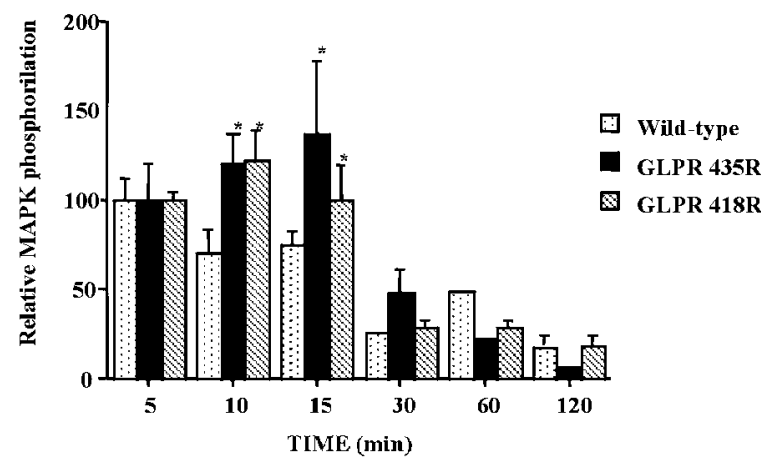

Figure 5 Effect of GLP-1(7-36)amide on phosphorylation of ERK1/ERK2 in CHO cells expressing wild-type and mutant GLP-1 receptors. CHO cells were treated with 10 nM GLP-1(7-36)amide for the indicated periods of time. Then, cell extracts were processed by SDS-PAGE and Western blot. Immunoblots against phospho-ERK1/ERK2 for cells expressing wild-type (A), GLPR 435R (B), and GLPR 418R (C) GLP-1 receptors are shown. The positions of immunoreactive phosphorylated forms of MAP kinase (MAPK) proteins 44 and $42 \mathrm{kDa}$ are indicated by the arrows. Similar results were obtained in three separate experiments. (D) Relative percentage of MAPK phosphorylation after stimulation with $10 \mathrm{nM}$ GLP-1 at different times. ${ }^{*} P<0 \cdot 05$ compared with cells expressing wild-type receptors (Newman-Keuls test).

and hypertonic treatment - a similar degree of inhibition of internalisation in cells expressing wild-type $(86.5 \%, 88 \%)$, GLPR $419 \Delta 435(75 \cdot 4 \%, 80 \cdot 7 \%)$ and GLPR A ${ }^{408-410}$ $(75 \%, 72 \%)$ receptors was observed (Fig. 6B). The effect of 
metabolic inhibitors and hypertonic medium was lower in cells expressing GLPR 435R receptors $(41.5 \%$ and 46.5\%), while in cells expressing GLPR 418R receptors

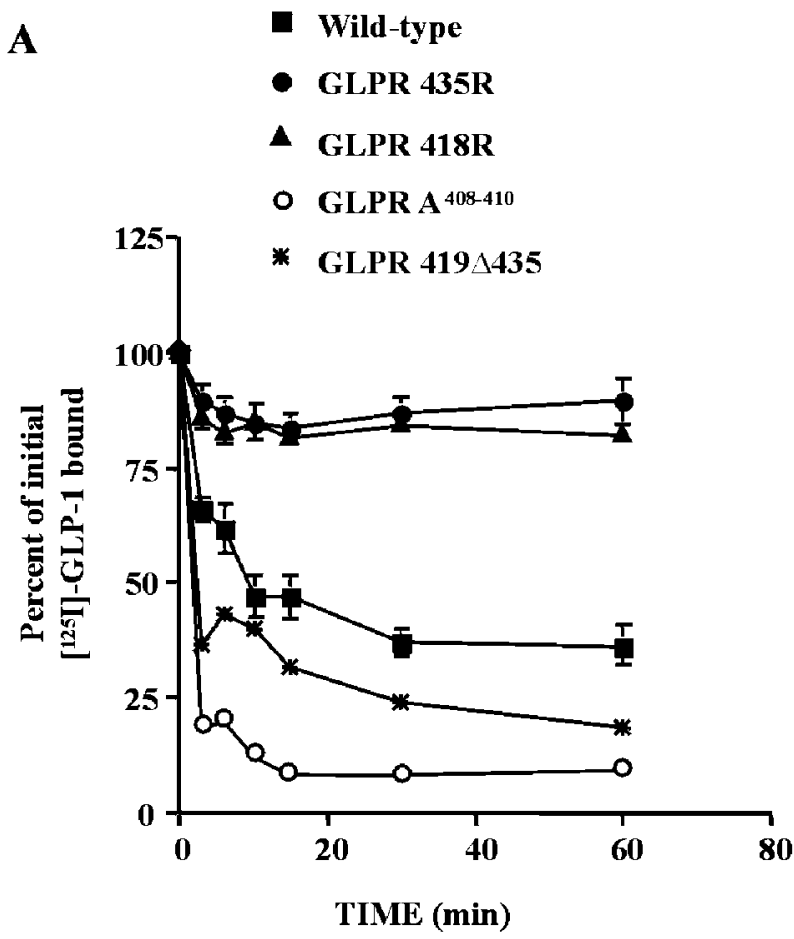

B

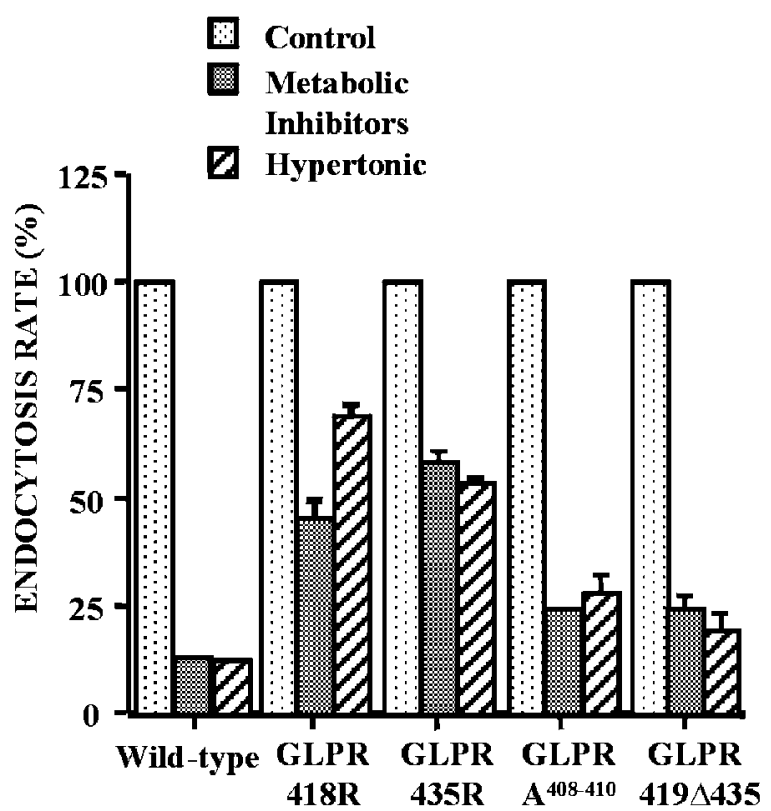

the inhibitory effect of metabolic depletion was $54.3 \%$ and the presence of hypertonic medium elicited a reduction of $31 \%$.

\section{Discussion}

Previous studies have indicated that the internalisation of GLP-1 receptors is dependent on phosphorylation in the 33 amino acid C-terminal tail. Our results show that the region in the neighbourhood of the VII transmembrane domain also contains additional sequence elements that regulate receptor internalisation. Thus, the results obtained in cells expressing C-terminal truncated mutants showed that deletion of the last 27 amino acids (cytoplasmic tail of 29 amino acids) decreased the internalisation rate by $78 \%$. These results are in agreement with previous findings using a mutant receptor lacking 33 amino acids in the C-terminal tail (Widmann et al. 1997). However, deletion of the 44 amino acids (cytoplasmic tail of 12 amino acids) elicited only a $47 \%$ slower internalisation rate than wildtype receptors. In an attempt to gain better insight into this process, we also studied the relationship between internalisation and other functional properties of GLP-1 receptors.

Truncated GLPR 435R and GLPR 418R mutant receptors bound the agonist with similar affinity to that of the wild-type receptors, but in cells expressing GLPR 435R the number of cell surface receptors was increased. The cross-linking assay also revealed that GLP-1(736)amide was specifically bound to those receptors.

To investigate the relationship between internalisation and signal transduction, we explored the ability of the different mutants of the GLP-1 receptor to stimulate adenylyl cyclase as well as the MAP kinase pathway. Our data revealed that receptors with a deletion of the last 27 or 44 amino acids of the cytoplasmic tail conserved a similar potency and efficacy in stimulating adenylyl cyclase. These data agree with the results reported using a mutant

Figure 6 Cell redistribution of wild-type and mutant GLP-1 receptors induced by their agonist, and the effect of metabolic inhibitors and hypertonic medium on endocytosis of wild-type and mutant GLP-1 receptors. (A) The effect of pretreatment with 10 nM GLP-1(7-36)amide for different periods of time on cell surface expression of GLP-1 receptors was investigated. Cells were incubated in the presence of agonist for different times. They were then washed and the ligand bound to the cell surface was removed by acid wash. Finally, ${ }^{125}$ I-GLP-1(7-36)amide binding to cell surface receptors was measured. Results are means \pm S.E.M. $(n=6)$. (B) CHO cells expressing wild-type or mutant GLP-1 receptors were preincubated in the absence (control) or presence of either hypertonic media or metabolic inhibitors for $30 \mathrm{~min}$. Then, $0 \cdot 1 \mathrm{nM}{ }^{125}$ I-GLP-1(7-36)amide was added and after 6 min of incubation total and acid wash-resistant cell-associated radioactivity was measured. The percentage of the rate of endocytosis was determined. Data represent means \pm S.E.M. of three independent experiments performed in triplicate. 
receptor lacking 33 amino acids from the C-terminal tail (Widmann et al. 1996) and similar results have been reported for glucagon receptors with C-terminal deletions (Buggy et al. 1997). The effect on the MAP kinase pathway was observed as an increase in phosphorylated forms of ERK-1/ERK-2 promoted by agonist stimulation in cells expressing wild-type GLP-1 receptors. Similar results have been reported previously in both RIN and CHO-GLPR cells (Montrose-Rafizadeh et al. 1999). Other members of this family of G-protein-coupled receptors, such as PTH receptors, also undergo increases in the phospho-ERK-1 form following agonist stimulation (Verheijen \& Defize 1997). The effect observed in cells expressing GLPR 435R and GLPR 418R mutant receptors was similar, but the increase in phosphorylated forms of ERK-1/ERK-2 persisted longer. It has previously been reported that stimulation of the MAP kinase pathway by $\beta$-adrenergic receptors requires the interaction of the ligand-receptor complex with adaptor proteins involved in the endocytic process, such as $\beta$-arrestins (Barlic et al. 2000). In our studies, we failed to observe any correlation between the phosphorylation of MAP kinases and the rate of internalisation.

Our data suggest an inhibitory role of the region containing amino acids 419-435 in the internalisation process. In further experiments, we analysed the effect of deletion of amino acids 419-435 and we also checked the effect of substitution by alanine of the three amino acids, $\mathrm{E}^{408}, \mathrm{~V}^{409}$ and $\mathrm{Q}^{410}$, close to transmembrane region VII, which are conserved in several members of this G-proteincoupled receptor subfamily. Mutant GLPR 419 435 and GLPR A ${ }^{408-410}$ receptors internalised faster (between $2 \cdot 3$ and 2.96 times) and showed a reduced cAMP production as compared with wild-type receptors. Deletion of residues 419-435 and substitution of EVQ by alanines in the GLP-1 receptors decreased the efficacy in stimulating adenylate cyclase activity by approximately $1 \cdot 8$ - and 3 -fold respectively. These results are in conflict with the notion that the production of this second messenger constitutes the switch to initiate the internalisation process (Widmann et al. 1995). Also, mutant receptors that fail to stimulate G-proteins show internalisation deficiencies (Behya et al. 1994, Moro et al. 1994). Our data are consistent with the results found for mutant receptors that interact with Gs and $\mathrm{Gq}$ but that show deficiencies in the internalisation process or those that do not interact with $\mathrm{Gs}$ and $\mathrm{Gq}$ and are internalised correctly (Cheung et al. 1990, Hunyady et al. 1994). Our data also suggest that endocytosis of the ligand-receptor complex favours its uncoupling from $G$ proteins. Mutant receptors that internalised faster had a reduced cAMP production with a similar $\mathrm{EC}_{50}$ potency. Our data also indicate a correlation between the rate of internalisation and the number of cell surface receptors. Thus, the highest level of GLP-1 receptors at the cell surface was found in cells expressing receptors deficient in internalisation (GLPR 435R), and cells expressing receptors that internalised faster than the wild-type (GLPR A $\mathrm{A}^{408-410}$ and GLPR 419 4435 ) expressed a reduced number of cell surface receptors.

The effects observed in the internalisation and signalling of mutant GLPR $419 \Delta 435$ and GLPR $A^{408-410}$ receptors might be due to conformational changes in the C-terminal region of the receptor, promoting the interaction of these mutant receptors with adaptor proteins and a faster internalisation. A conformational change of the $\mathrm{C}$-terminal tail has also been proposed to explain the results obtained after mutation of a small region in the proximal portion of the carboxyl tail in $\beta$-adrenergic receptors (Hausdorff et al. 1991). However, in that case the substitution of residues in this region blocked the sequestration and phosphorylation of these receptors. The region of receptor amino acids from 419-435 contains $\mathrm{Ser}^{431 / 432}$, the consensus sequence for protein kinase $\mathrm{C}$. The absence of these residues might regulate the phosphorylation of three doublets involved in the internalisation process: $\operatorname{Ser}^{441 / 442}, \operatorname{Ser}^{444 / 445}$ and Ser ${ }^{451 / 452}$. However, we have previously reported that substitution of $\operatorname{Ser}^{431 / 432}$ by alanine did not modify either the rate of endocytosis or the potency or efficacy of these receptors in stimulating adenylate cyclase (Vázquez et al. 2005).

The differences in the rate of internalisation also affected the redistribution promoted by agonist exposure. After 15-min exposure with GLP-1(7-36)amide, cells expressing wild-type receptors conserved $45-50 \%$ of their cell surface receptors. These data are comparable to the results reported for glucagon receptor internalisation: 40$50 \%$ of cell surface receptors were internalised in $10 \mathrm{~min}$ (Buggy et al. 1997). Cells expressing the truncated mutant receptors GLPR 435R and GLPR 418R, in contrast to cells expressing the wild-type, preserved $80-85 \%$ of the initial cell surface receptor numbers. However, cells expressing GLPR $419 \Delta 435$ and GLPR A A $^{408-410}$ conserved only $37 \%$ and $20 \%$ of their cell surface receptors respectively after 3-min exposure to the agonist. All these data indicate that, after agonist exposure, cell surface receptors are essentially dependent on the rate of endocytosis, although our findings also suggest differences in the recycling time. Cells expressing GLPR 418R receptors maintained a number of cell surface receptors after exposure to the agonist, similar to cells expressing GLPR 435R receptors; however, the rate of endocytosis was twofold slower for the latter type of receptor.

The data concerning internalisation for receptors lacking the 44 amino acids of the C-terminal tail led us to investigate whether these receptors were internalised through coated pits or through a different pathway. This region contains all the phosphorylation sites so far identified for GLP-1 receptors and previously described to mediate the process of endocytosis by coated pits. The results obtained after hypertonic medium treatment revealed that GLP-1 receptors are mainly internalised by coated pits in cells expressing wild-type and mutant 
receptors, except in those expressing GLPR 418R, and that $15-25 \%$ of the rate of endocytosis measured was not dependent on metabolic energy. In the endocytosis experiments, intracellular-associated radioactivity was measured after an acid wash, a procedure that in all cases eliminated $80-90 \%$ of the radioactivity bound to the cell surface. The percentage of internalisation not dependent on metabolic energy was higher for cells expressing truncated receptors. It is possible that some of these receptors could enter the cell through a pathway that is not dependent on metabolic energy. The presence of hypertonic medium in cells expressing GLPR 418R receptors did not disturb the internalisation of $30 \%$ of the receptors, suggesting that these receptors might be internalised by both coated and uncoated pits. Similar results have been reported previously for cells expressing truncated PTH receptors (Huang et al. 1995). These data could also explain the faster rate of resensitisation in cells expressing GLPR 418R receptors. The cholecystokinin A receptor has been reported to be internalised through coated pits and uncoated pits and the authors of that paper suggested that the uncoated pit pathway might be involved in the rapid resensitisation of those receptors (Roettger et al. 1995).

Our results show that the proximal portion of the carboxyl tail of GLP-1 receptors contains sequence elements that regulate agonist-dependent internalisation. Mutations in this GLP-1 receptor region might change the conformation of the cytoplasmic tail and hence alter its functional activity.

\section{Acknowledgements}

This study was supported by grants from Dirección General de Investigación Científica y Técnica (DGICYT), Fondo de Investigación Sanitaria, Instituto Carlos III RGDM (G03/212) and RCMN (C03/08), and the Comunidad de Madrid, Spain. The authors declare that there is no conflict of interest that would prejudice the impartiality of this scientific work.

\section{References}

Alvarez E, Girones N \& Davis RJ 1990 Inhibition of the receptor-mediated endocytosis of diferric transferrin is associated with the covalent modification of the transferrin receptor with palmitic acid. Journal of Biological Chemistry 265 16644-16655.

Alvarez E, Roncero I, Chowen JA, Thorens B \& Blázquez E 1996 Expression of the glucagon-like peptide-1 receptor gene in rat brain. Journal of Neurochemistry 66 920-927.

Barlic J, Andrews JD, Kelvin AA, Bosinger SE, Dobransky T, Feldman RD, Fergusson SSG \& Kelvin DJ 2000 Regulation by Cxcr1 of tyrosine kinase activation and granule release through $\beta$-arrestin. Nature Immunology 1 227-233.

Barragán JM, Rodriguez R \& Blázquez E 1994 Changes in arterial blood pressure and heart rate induced by glucagon-like peptide-1(7-36)amide in rats. American Journal of Physiology 266 E459-E466.
Behya RV, Akeson M, Mrozinssk J, Jensen RT \& Battey JF 1994 Internalisation of the gastrin-releasing peptide receptor is mediated by both phospholipase C-dependent and -independent processes. Molecular Pharmacology 46 495-501.

Benito E, Blázquez E \& Bosch M 1998 Glucagon-like peptide-1(7-36)amide increases pulmonary surfactant secretion through a cyclic adenosine $3^{\prime}, 5^{\prime}$-monophosphate-dependent protein kinase mechanism in rat type II pneumocytes. Endocrinology 139 2363-2368.

Benya RV, Fathi Z, Battey JF \& Jensen RT 1993 Serines and threonines in the gastrin-releasing peptide receptor carboxyl terminus mediate internalisation. Journal of Biological Chemistry 268 20285-20290.

Böhn SK, Khitin LM, Smeekens SP, Grady EF, Payan DG \& Bunnett NW 1997a Identification of potential tyrosine-containing endocytic motifs in the carboxyl-tail and seventh transmembrane domain of the neurokinin 1 receptor. Journal of Biological Chemistry 272 2363-2372.

Böhn SK, Grady EF \& Bunnett NW $1997 b$ Regulatory mechanisms that modulate signalling by G-protein. Biochemical Journal 322 1-18.

Buggy JJ, Heurich RO, MacDougall M, Kelly KA, Livingston JN, Yoo-Warren H \& Rossomando AJ 1997 Role of the glucagon receptor $\mathrm{COOH}$-terminal domain in glucagon-mediated signalling and receptor internalisation. Diabetes 46 1400-1405.

Calvo JC, Yusta B, Mora F \& Blázquez E 1995 Structural characterization by affinity cross-linking of glucagon-like peptide-1(7-36)amide receptor in rat brain. Journal of Neurochemistry 64 299-306.

Chang MP, Mallet WG, Mostov KE \& Brodsky FM 1993 Adaptor self-aggregation, adaptor-receptor recognition and binding of alpha-adaptin subunits to the plasma membrane contribute to recruitment of adaptor (AP2) components of clathrin-coated pits. EMBO Journal 12 2169-2180.

Chen C \& Okayama H 1987 High-efficiency transformation of mammalian cells by plasmid DNA. Molecular and Cellular Biology 7 2745-2752.

Cheng Y \& Prusoff WH 1973 Relationship between the inhibition constant $\left(K_{\mathrm{I}}\right)$ and the concentration of inhibitor which causes 50 per cent inhibition $\left(\mathrm{I}_{50}\right)$ of an enzymatic reaction. Biochemical Pharmacology 22 3099-3108.

Cheung AH, Dixon RA, Hill WS, Sigal IS \& Strader CD 1990 Separation of the structural requirements for agonist-promoted activation and sequestration of the beta-adrenergic receptor. Molecular Pharmacology 37 775-779.

Clague MJ 1998 Molecular aspects of the endocytic pathway. Biochemical Journal 336 271-282.

Dillon JS, Tanizawa Y, Wheeler MB, Leng X-H, Ligon BB, Rabin DU, Yoo-Warren H, Permutt MA \& Boyd AE III 1993 Cloning and functional expression of the human glucagon-like peptide-1 (GLP-1) receptor. Endocrinology 133 1907-1910.

Ferguson SSG 2001 Evolving concepts in G-protein-coupled receptor endocytosis: the role in receptor desensitization and signalling. Pharmacological Reviews 53 1-24.

Ferguson SSG, Downey III WJ, Colapietro A-M, Barak LS, Ménard L \& Caron MG 1996 Role of $\beta$-arrestin in mediating agonist-promoted G-protein-coupled receptor internalisation. Science $271363-366$

Freedman NJ \& Lefkowitz RJ 1996 Desensitization of G-proteincoupled receptors. Recent Progress in Hormone Research 51 319-353.

Garland AM, Grady EF, Lovett M, Vigna SR, Frucht MM, Krause JE \& Bunnett NW 1996 Mechanism of desensitization and resensitization of G-protein-coupled neurokinin 1 and neurokinin 2 receptors. Molecular Pharmacology 49 438-446.

Ghinea N, Vu Hai MT, Groyer-Picard MT, Houllier A, Schoevaert D \& Milgrom E 1992 Pathways of internalisation of the hCG/LH receptor: immunoelectron microscopic studies in Leydig cells and transfected L-cells. Journal of Cell Biology 118 1347-1358. 
Goodman OB, Krupnick JG, Santini F, Gurevich W, Penn RB, Gagnon AW, Keen JH \& Benovic JL 1996 Beta-arrestin acts as a clathrin adaptor in endocytosis of the $\beta_{2}$-adrenergic receptor. Nature 383 447-450.

Hansen SH, Sandvig K \& van Deurs B 1993 Clathrin and HA2 adaptors: effects of potassium depletion, hypertonic medium, and cytosol acidification. Journal of Cell Biology 121 61-72.

Hausdorff WP, Campbell PT, Ostrowski J. Yu SS, Caron MG \& Lefkowitz RJ 1991 A small region of the $\beta$-adrenergic receptor is selectively involved in its rapid regulation. PNAS $\mathbf{8 8}$ 2979-2983.

Heuser JE \& Anderson RG 1989 Hypertonic media inhibit receptor-mediated endocytosis by blocking clathrin-coated pit formation. Journal of Cell Biology 108 389-400.

Hoxie JA, Ahuja M, Belmonte E, Pizarro S, Parton R \& Brass LF 1993 Internalisation and recycling of activated thrombin receptors. Journal of Biological Chemistry 268 13756-13763.

Huang Z, Chen Y \& Nissenson RA 1995 The cytoplasmic tail of the G-protein-coupled receptor for parathyroid hormone and parathyroid hormone-related protein contains positive and negative signals for endocytosis. Journal of Biological Chemistry 270 151-156.

Hunyady L, Baukal AJ, Balla T \& Catt KJ 1994 Independence of type I angiotensin II receptor endocytosis from $\mathrm{G}$ protein coupling and signal transduction. Journal of Biological Chemistry 269 24798-24804.

Kreymann B, Williams G, Ghatei MA \& Bloom SR 1987 Glucagon-like peptide-1(7-36): a physiological incretin in man. Lancet 2 1300-1304.

Laemmli UK 1970 Cleavage of structural proteins during the assembly of the head of bacteriophage T4. Nature 227 680-685.

Lohse MJ 1993 Molecular mechanism of membrane receptor desensitization. Biochimica et Biophysica Acta (BBA) 1179 171-188.

Montrose-Rafizadeh C, Avdonin P, Garant MJ, Rodgers BD, Kole S, Yang H, Levine MA, Schwindinger W \& Bernier M 1999 Pancreatic glucagon-like peptide-1 receptor couples to multiple G proteins and activates mitogen-activated protein kinase pathways in Chinese hamster ovary cells. Endocrinology 140 1132-1140.

Moro O, Shockley MS, Lameh J \& Sadée W 1994 Overlapping multi-site domains of the muscarinic cholinergic $\mathrm{Hm} 1$ receptor involved in signal transduction and sequestration. Journal of Biological Chemistry $2696651-6655$.

Navarro M, Rodriguez de Fonseca F, Alvarez E, Chowen JA, Zueco JA, Gómez R, Eng J \& Blázquez E 1996 Colocalization of glucagon-like peptide-1 (GLP-1) receptors, glucose transporter GLUT-2, and glucokinase mRNAs in rat hypothalamic cells: evidence for a role of GLP-1 receptor agonists as an inhibitory signal for food and water intake. Journal of Neurochemistry 67 1982-1991.

Ohno H, Stewart J, Fournier M-C, Bosshart H, Rhee I, Miyatake J, Saito T, Galluser A, Kirchhausen T \& Bonifacino JS 1995 Interaction of tyrosine-based sorting signals with clathrin-associated proteins. Science 269 1872-1875.

Pawson T \& Scott JD 1997 Signalling through scaffold, anchoring and adaptor proteins. Science 278 2075-2080.

Pipping S, Andexinger S \& Lohse MJ 1995 Sequestration and recycling of $\beta_{2}$-adrenergic receptors permit receptor resensitization. Molecular Pharmacology 47 666-676.

Raposo G, Dunia I, Delavier-Klutchko C, Kaveri S, Strosberg AD \& Benedetti EL 1989 Internalisation of beta-adrenergic receptor in A431 cells involves non-coated vesicles. European Journal of Cell Biology 50 340-352.

Rodriguez de Fonseca F, Navarro M, Alvarez E, Roncero I, Chowen JA, Maestre O, Gómez R, Muñoz RM, Eng J \& Blázquez E 2000 Peripheral versus central effects of glucagon-like peptide- 1 on satiety and body weight loss in Zucker obese rats. Metabolism 49 $1-10$.
Roettger BF, Rentsch RU, Pinon D, Holicky E, Hadac E, Larkin JM \& Miller LJ 1995 Dual pathways of internalisation of the cholecystokinin. Journal of Cell Biology 128 1029-1041.

Sorkin A \& Carpenter G 1993 Interaction of activated EGF receptors with coated pit adaptins. Science 261 612-615.

Tang-Christensen M, Larsen PJ, Goke R, Fink-Jensen A, Jessop D, Moller M \& Sheikh SP 1996 Central administration of GLP-1(7-36)amide inhibits food and water intake in rats. American Journal of Physiology 271 R848-R856.

Thomas WG, Baker KM, Motel TJ \& Thekkumkara TJ 1995 Angiotensin II receptor endocytosis involves two distinct regions of the cytoplasmic tail. Journal of Biological Chemistry 270 22153-22159.

Thorens B 1993 Expression cloning of the pancreatic $\beta$ cell receptor for the gluco-incretin hormone glucagon-like peptide-1. PNAS $\mathbf{8 9}$ $8641-8645$.

Thorens B, Porret A, Bühler L, Deng S-P, Morel P \& Widmann C 1993 Cloning and functional expression of the human islet GLP-1 receptor: demonstration that exendin-4 is an agonist and exendin(9-39) an antagonist of the receptor. Diabetes $\mathbf{4 2}$ $1678-1682$.

Toft-Nielsen MB, Madsbad S \& Holst JJ 1999 Continuous subcutaneous infusion of glucagon-like peptide-1 lowers plasma glucose and reduces appetite in type 2 diabetic patients. Diabetes Care 22 1137-1143.

Trowbridge IS, Collawn JF \& Hopkins CR 1993 Signal-dependent membrane protein trafficking in the endocytic pathway. Annual Review of Cell and Developmental Biology 9 129-161.

Turton MD, O'Shea D, Gunn I, Beak SA, Edwards CMB, Meeran K, Choi SJ, Taylor GM, Heath MM, Lambert PD, Wilding JPH, Smith DM, Ghatei MA, Herbert J \& Bloom SR 1996 A role for glucagon-like peptide-1 in the central regulation of feeding. Nature 379 69-72.

Vázquez P, Roncero I, Blázquez, \& Alvarez E 2005 Substitution of the cysteine 438 residue in the cytoplasmic tail of the glucagon-like peptide- 1 receptor alters signal transduction activity. Journal of Endocrinology 185 35-44.

Verheijen MJ \& Defize LH 1997 Parathyroid hormone activates mitogen-activated protein kinase via a cAMP-mediated pathway independent of Ras. Journal of Biological Chemistry 272 3423-3429.

Von Zastrow M \& Kobilka BK 1992 Ligand-regulated internalisation and recycling of human beta 2-adrenergic receptors between the plasma membrane and endosomes containing transferrin receptor. Journal of Biological Chemistry 267 3530-3538.

Von Zastrow M, Link R, Daunt D, Barsh G \& Kobilka BK 1993 Subtype-specific differences in the intracellular sorting of G-protein-coupled receptors. Journal of Biological Chemistry 268 763-766.

Weir GC, Mojsov S, Hendrich GK \& Habener JF 1989 Glucagon-like peptide-1(7-37) actions on endocrine pancreas. Diabetes 38 338-342.

Widmann CH, Dolci W \& Thorens B 1995 Agonist-induced internalisation and recycling of the glucagon-like peptide-1 receptor in transfected fibroblasts and in insulinomas. Biochemical Journal $\mathbf{3 1 0}$ 203-214.

Widmann CH, Dolci W \& Thorens B 1996 Desensitization and phosphorylation of the glucagon-like peptide-1 (GLP-1) receptor by GLP-1 and 4-phorbol 12-myristate 13-acetate. Molecular Endocrinology 10 62-75.

Widmann CH, Dolci W \& Thorens B 1997 Internalisation and homologous desensitization of the GLP-1 receptor dependent on phosphorylation of the receptor carboxyl tail at the same three sites. Molecular Endocrinology 11 1094-1102.

Received 22 April 2005

Accepted 28 April 2005 